\title{
Metabolic Syndrome and time to pregnancy: a retrospective study of nulliparous women
}

DOI:

10.1111/1471-0528.15647

\section{Document Version}

Accepted author manuscript

Link to publication record in Manchester Research Explorer

\section{Citation for published version (APA):}

Grieger, J. A., Grzeskowiak, L. E., Smithers, L. G., Bianco-miotto, T., Leemaqz, S. Y., Andraweera, P., Poston, L., Mccowan, L. M., Kenny, L. C., Myers, J., Walker, J. J., Norman, R. J., Dekker, G. A., \& Roberts, C. T. (2019). Metabolic Syndrome and time to pregnancy: a retrospective study of nulliparous women. BJOG: An International Journal of Obstetrics \& Gynaecology. https://doi.org/10.1111/1471-0528.15647

\section{Published in:}

BJOG: An International Journal of Obstetrics \& Gynaecology

\section{Citing this paper}

Please note that where the full-text provided on Manchester Research Explorer is the Author Accepted Manuscript or Proof version this may differ from the final Published version. If citing, it is advised that you check and use the publisher's definitive version.

\section{General rights}

Copyright and moral rights for the publications made accessible in the Research Explorer are retained by the authors and/or other copyright owners and it is a condition of accessing publications that users recognise and abide by the legal requirements associated with these rights.

\section{Takedown policy}

If you believe that this document breaches copyright please refer to the University of Manchester's Takedown Procedures [http://man.ac.uk/04Y6Bo] or contact uml.scholarlycommunications@manchester.ac.uk providing relevant details, so we can investigate your claim.

\section{OPEN ACCESS}


1 Metabolic Syndrome and time to pregnancy: a retrospective study of nulliparous women

2

3

$4 \quad$ Running title: Metabolic syndrome and fertility

5

6 Jessica A Grieger ${ }^{\mathrm{a}, \mathrm{b}^{*}}$, Luke E Grzeskowiak ${ }^{\mathrm{a}, \mathrm{b}}$, Lisa G Smithers ${ }^{\mathrm{a}, \mathrm{c}}$, Tina Bianco-Miotto ${ }^{\mathrm{a}, \mathrm{d}}$,

7 Shalem Y Leemaqz ${ }^{\mathrm{a}, \mathrm{b}}$, Prabha Andraweera ${ }^{\mathrm{a}, \mathrm{b}}$, Lucilla Poston ${ }^{\mathrm{e}}$, Lesley M McCowan ${ }^{\mathrm{f}}$, Louise C

8 Kenny $^{\mathrm{g}}$, Jenny Myers ${ }^{\mathrm{h}}$, James J Walker ${ }^{\mathrm{i}}$, Robert J Norman ${ }^{\mathrm{a}, \mathrm{j}}$, Gus A Dekker ${ }^{\mathrm{a}, \mathrm{k}}$, Claire T

9 Roberts ${ }^{\mathrm{a}, \mathrm{b}}$,

10

11 JAG and LEG are joint first authors.

12

$13 *$ Corresponding author: jessica.grieger@adelaide.edu.au

14

15 a Robinson Research Institute, University of Adelaide, North Adelaide, SA, 5006, Australia;

16 b Adelaide Medical School, North Terrace, University of Adelaide, Adelaide, SA, 5000,

17 Australia

$18{ }^{\mathrm{c}}$ School of Public Health, University of Adelaide, Adelaide 5000, Australia

$19{ }^{\mathrm{d}}$ Waite Research Institute, School of Agriculture, Food and Wine, University of Adelaide,

20 Adelaide 5064, Australia

21 e Department of Women and Children's Health, King's College London, St. Thomas's

22 Hospital, Westminster Bridge, London SE1 7EH

$23{ }^{\mathrm{f}}$ Department of Obstetrics and Gynaecology, University of Auckland, Auckland 1142, NZ

24 g Faculty of Health \& Life Sciences, University of Liverpool, Foundation Building, 765

25 Brownlow Hill Liverpool, L69 7ZX 
$26{ }^{\mathrm{h}}$ Maternal and Fetal Health Research Centre, University of Manchester, Manchester Academic 27 Health Science Centre, Manchester M13 9WL, UK

$28{ }^{\mathrm{i}}$ Obstetrics and Gynaecology Section, Leeds Institute of Biomedical and Clinical Sciences,

29 University of Leeds, Leeds, UK

$30 \quad$ j Fertility SA, Adelaide, South Australia, 5000, Australia.

$31{ }^{k}$ Women and Children's Division, Lyell McEwin Hospital, University of Adelaide, Adelaide 325112 , Australia

33

34

35 
Objectives: To determine 1) the association between metabolic syndrome (MetS), time to pregnancy (TTP), and infertility 2) associations between individual and increasing number of MetS components, TTP, and infertility; 3) whether these relationships differ by obesity (BMI, $<30 \mathrm{~kg} / \mathrm{m}^{2}$ vs. $\left.\geq 30 \mathrm{~kg} / \mathrm{m}^{2}\right)$

40 Design: Retrospective cohort study.

41 Setting: Multi-centre (Australia, United Kingdom, New Zealand, Ireland).

Population: 5519 low-risk nulliparous pregnant women.

Methods: Data on retrospectively reported TTP (number of months to conceive) and a blood sample to assess metabolic health were collected between 14-16 weeks' gestation. MetS was defined according to the International Diabetes Federation criteria. Accelerated failure time models with log normal distribution were conducted to estimate time ratios (TR) and 95\% CIs. Differences in MetS on infertility (TTP $>12$ months) was compared using a generalized linear model (Poisson distribution) with robust variance estimates (RR; 95\% CIs). All analyses (entire cohort and split by BMI) were controlled for a range of maternal and paternal confounders.

Main Outcome Measures: TTP and infertility.

Results: Of the 5519 women included, $12.4 \%(n=684)$ had MetS. Compared to women without MetS, women with MetS had a longer TTP (adjusted TR 1.30; 95\% CI: 1.15-1.46), which was similar in the obese and non-obese women. Marginal estimates for median TTP in women with MetS vs. without MetS was 3.1 (3.0-3.3) months vs. 4.1 (3.6-4.5) months, respectively. Women with MetS were at a $62 \%$ greater risk for infertility and were at a greater risk for infertility whether they were obese (adjusted RR 1.62; 1.15-2.29) or not (adjusted RR 1.73; 1.33-2.23). Reduced HDL-C and raised TG were the main individual components associated with risk for infertility.

Conclusions: MetS is associated with longer TTP and infertility, independent of obesity.

60 Additional studies, pre-pregnancy, are required to support our findings and to determine the 
61 applicability of which combinations of metabolic abnormalities pose greatest risk to delayed

62 fertility, or whether individual components are amenable to modification.

63

64 Keywords: metabolic syndrome, lipids, pregnancy, fecundity, time to pregnancy, infertility, 65 retrospective study

66

67 Tweetable abstract: MetS associates with longer time to pregnancy and infertility, 68 independent of obesity. 
Introduction

Metabolic health encompasses metabolic, vascular and inflammatory markers, and a clustering of metabolic health abnormalities is called metabolic syndrome (MetS). While cardiometabolic risk factors often cluster together and commonly associate with obesity ${ }^{1}$, obesity and MetS can also exist independently ${ }^{2-4}$.

Time to pregnancy (TTP) is a measure of how long a couple takes to conceive and infertility is the failure to achieve pregnancy after 12 months or more of regular unprotected sexual intercourse ${ }^{5}$. Obesity is consistently associated with impaired fertility ${ }^{6,7}$, however, assessment of MetS has not been widely assessed in relation to infertility. Evidence from human studies in women diagnosed with or receiving treatments for infertility, have shown individual metabolic components such as raised triglycerides, total cholesterol, or low density lipoprotein cholesterol, or reduced levels of high density lipoprotein cholesterol was associated with infertility ${ }^{8}$ or longer TTP ${ }^{9}$. In couples planning a pregnancy, raised concentrations of free cholesterol were associated with longer TTP ${ }^{10}$.

Emerging evidence also suggests a link between infertility and cardiovascular disease (CVD). A recent study demonstrated that women who reported infertility had 1.83 times higher odds of having experienced a cardiovascular event compared to women who had never experienced infertility ${ }^{11}$. In the adult population, the utility of MetS in predicting CVD compared to its individual risk factors has been debated ${ }^{12-14}$. However, given the reported associations between individual MetS components and fertility and the recent evidence of the association between infertility and CVD, the current study presents a unique opportunity to investigate whether MetS associates with TTP and infertility.

In the adult population, the utility of MetS in predicting cardiovascular disease (CVD) compared to its individual risk factors has been debated ${ }^{12-14}$. However, given the reported 
associations between individual MetS components and fertility, and CVD, the current study presents a unique opportunity to investigate whether MetS associates with TTP and infertility. We hypothesise that MetS is associated with a longer TTP and a higher rate of infertility. The study objectives were three-fold: 1) to determine the association between MetS, TTP, and infertility 2) to examine associations between individual and increasing number of MetS components, TTP, and infertility; 3) to determine whether these relationships differ by obesity status (body mass index, $<30 \mathrm{~kg} / \mathrm{m}^{2} \mathrm{vs} . \geq 30 \mathrm{~kg} / \mathrm{m}^{2}$ ).

\section{Materials and Methods}

\section{Study population}

The Screening for Pregnancy Endpoints study (SCOPE) is a multi-centre prospective cohort study which recruited nulliparous women with singleton pregnancies from Adelaide (Australia), Auckland (New Zealand), Cork (Ireland), Leeds, London and Manchester (UK) $(\mathrm{n}=5628)$. The primary aim of SCOPE was the development of screening tests for prediction of preeclampsia, spontaneous preterm birth and small for gestational age babies. Recruitment was between November 2004 and February 2011. Included women were nulliparous with singleton pregnancies. Exclusion criteria and detailed descriptions of the SCOPE study have been published previously ${ }^{15}$.

Ethics approval was obtained from local ethics committees [New Zealand AKX/02/00/364, Australia REC 1712/5/2008, London, Leeds and Manchester 06/MRE01/98 and Cork ECM5 (10) 05/02/08] and all women provided written informed consent. Core outcome sets were not used, and women were not involved in the development of the research question or study outcomes. The Australian SCOPE study was funded by the Premier's Science and Research Fund, South Australian Government (http://www.dfeest.sa.gov.au/scienceresearch/premiers-research-and-industry-fund). The New Zealand SCOPE study was funded 
118 by the New Enterprise Research Fund, Foundation for Research Science and Technology;

119 Health Research Council (04/198); Evelyn Bond Fund, Auckland District Health Board

120 Charitable Trust. The Irish SCOPE study was funded by the Health Research Board of Ireland

121 (CSA/2007/2; http://www.hrb.ie). The UK SCOPE study was funded by National Health

122 Service NEAT Grant (Neat Grant FSD025), Biotechnology and Biological Sciences Research

123 council (www. bbsrc.ac.uk/funding; GT084) and University of Manchester Proof of Concept

124 Funding (University of Manchester); Guy’s and St. Thomas' Charity (King's College London)

125 and Tommy's charity (http://www. tommys.org/; King's College London and University of

126 Manchester); and Cerebra UK (www.cerebra.org.uk; University of Leeds). L.E. Grzeskowiak

127 is supported by an Australian National Health and Medical Research Council (NHMRC) Early

128 Career Fellowship (ID 1070421). L.C. Kenny is supported by a Science Foundation Ireland

129 Program Grant for INFANT (12/RC/2272). C.T. Roberts was supported by a National Health

130 and Medical Research Council (NHMRC) Senior Research Fellowship (GNT1020749). The

131 funding source(s) had no involvement in the conduct of the research nor in the preparation of

132 the manuscript.

Data collection

135 Data were collected by a research midwife at 14-16 weeks' gestation. Information was

136 collected at each study centre (Adelaide, Auckland, Cork, Leeds, London, Manchester) on

137 demographics, smoking, family, medical and gynecological history, and diet and supplement

138 use. Weight and height (to determine BMI) were measured without shoes, or jacket, to the

139 nearest $0.1 \mathrm{~kg}$ and $\mathrm{cm}$, respectively. Waist circumference (WC) was measured using a tape

140 measure, at the point half way between the top of the hip (iliac crest) and inferior margin of

141 lowest rib. Two consecutive manual blood pressure measurements (mercury or aneroid

142 sphygmomanometer, with a large cuff if the arm circumference $\geq 33 \mathrm{~cm}$ and Korotkoff $\mathrm{V}$ for 
143 diastolic blood pressure) were recorded. Women reported if the current conception was

144 associated with the use of any fertility treatments (e.g. IVF, ICSI, ovulation induction). A non-

145 fasting blood sample was taken for measurement of HDL-C and TG at the same visit and a

146 random whole blood glucose was measured using a glucometer, as fasting glucose samples

147 were not available for all women in all centers. Details of immunoassay methodology for 148 measuring lipids can be found in previous publications ${ }^{16,17}$.

Assessment of exposure (metabolic syndrome)

151 MetS was defined according to the International Diabetes Federation (IDF) criteria ${ }^{18}$. The IDF

152 criteria cut-points are the same as the National Cholesterol Education Program Adult Treatment Panel III (NCEP ATP III) ${ }^{19}$, except for glucose and WC which are both slightly lower in IDF, and in NCEP ATP III, WC is not a pre-requisite in determining MetS. The IDF criteria was chosen because the cut-point for WC aligns with the World Health Organisation guidelines ${ }^{20}$ and because WC provides a unique indicator of body fat distribution, which can identify

157 patients who are at increased risk for obesity-related cardiometabolic disease, above and beyond the measurement of $\mathrm{BMI}{ }^{21}$. A $\mathrm{WC} \geq 80 \mathrm{~cm}$ is a prerequisite risk factor, along with any 2 of the 4 variables: raised TG $[\geq 1.70 \mathrm{mmol} / \mathrm{L}(\geq 150 \mathrm{mg} / \mathrm{dl})]$, reduced HDL-C $[<1.29 \mathrm{mmol} / \mathrm{L}$

$160(<50 \mathrm{mg} / \mathrm{dL})]$, raised $\mathrm{BP}$ (i.e. systolic $\mathrm{BP} \geq 130 \mathrm{mmHg}$ or diastolic $\mathrm{BP} \geq 85 \mathrm{mmHg}$ ), or raised 161 fasting plasma glucose $(\geq 5.6 \mathrm{mmol} / \mathrm{L})$. As this was a pregnancy cohort, a random plasma glucose sample was measured, however the same concentration cut-off was used as IDF criteria $(\geq 5.6 \mathrm{mmol} / \mathrm{L})$.

Assessment of outcome

166 Estimates of retrospectively reported TTP were derived from the following question "duration of sex without contraception before conception with father of baby". Values, in months, were 
recorded in a continuous fashion and used to define TTP. For this purpose of this study, infertility was defined as having a TTP of more than 12 months or use of assisted reproductive technologies. Women who conceived in their first month had a reported TTP of 1 month, with prolonged TTP censored at 12-months of attempting to conceive.

\section{Assessment of covariates}

Maternal ethnicity was self-reported and binary coded as Caucasian or other $(90 \%$ were Caucasian). The socioeconomic index was developed in New Zealand and is a measure of the individual's socioeconomic position derived from a specific occupation ${ }^{22}$. It provides a value of 10-90 with a higher score indicating higher socioeconomic position ${ }^{23}$. Women who had $\geq 1$ of any previous miscarriage at $\leq 10$ weeks' gestation or $>10$ weeks' gestation were binary coded as yes/no for previous miscarriage. Retrospectively reported data at this same visit was also obtained: cigarette use and any intake of alcohol per week in the 3 months pre-pregnancy were binary coded as yes or no. Number of servings of fruit (fresh fruit and fruit juice), green leafy vegetables (vegetables high in folate such as spinach, cabbage, lettuce, broccoli), fish (with prompts of fish such as salmon, trout, sardines, shellfish and shrimp) and "fast food" (frequency of intake of burgers, fried chicken, pizza, and hot chips) have been described previously ${ }^{24}$. Paternal data, including paternal age, and paternal height and weight (to calculate BMI), was self-reported from the biological father at the first (14-16 weeks' gestation) or second (19-21 weeks' gestation) antenatal visit, or after the baby was born.

\section{Statistical analyses}

Frequencies and descriptive statistics of all women were expressed as $n(\%)$ or as means (standard deviation, SD). Median [inter-quartile range, IQR] was reported when continuous variables were not normally distributed. The impact of MetS on TTP was investigated using 
193

194

195

196

197

198

200

201

202

203

204

205

206

207

208

209

210

211

212

213

214

215

216

217

accelerated failure time models ${ }^{25}$ with log normal distribution to estimate time ratios (TR) and 95\% CIs. Adjusted marginal estimates for median TTP according to MetS status were calculated using the STATA 'margins' command, together with corresponding 95\% CIs. Alternative distributions were investigated but the log normal distribution was selected based on providing the lowest $-2 \log$ likelihood and Akaike information criterion value. These TRs can be interpreted as the ratios of the median values of the duration (in months) to achieve pregnancy between the compared groups. A TR above 1 implies that a given exposure is associated with longer TTP, whereas a TR below 1 indicates a shorter TTP. The impact of MetS, analysed i) a composite, ii) each metabolic component, and iii) with increasing number of MetS components above the IDF cut-point, and infertility, was compared using a generalized linear model (Poisson distribution) with robust variance estimates, with resulting relative risks (RR) and 95\% CIs. The association between MetS, its individual components, and with increasing number of MetS components were assessed in the entire cohort and split by women who had a non-obese $\left(<30.0 \mathrm{~kg} / \mathrm{m}^{2}\right)$ or obese $\left(\geq 30 \mathrm{~kg} / \mathrm{m}^{2}\right)$ BMI.

We used causal diagrams (directed acyclic graphs) to guide selection of potential confounders for which to control, based on a priori selection of variables considered to be a common cause of MetS and fertility. Two separate adjusted models were used. Model 1: maternal BMI, maternal age, SEI, study centre, ethnicity (Caucasian/other), previous miscarriage (yes/no), smoking status (yes/no), alcohol intake (yes/no); Model 2: model 1 plus maternal dietary intake prior to conception, paternal age, paternal BMI. The individual MetS risk factors were not included as covariates and models for each MetS component were run individually. This was a complete case analysis.

Sensitivity analyses were performed to evaluate the robustness of the results, which were selected based on key potential sources of bias in retrospective TTP studies ${ }^{26}$. Truncation bias is possible where TTP distributions or covariates are nonstationary over time and is 
218 particularly important where exposures may vary systematically over time ${ }^{26}$. The potential for

219 truncation bias was corrected for by restricting the analysis to women with a starting time

220 between the second year and penultimate year of participant recruitment at each site $(n=3662)$

221 to account for left and right truncation bias, respectively ${ }^{26}$. The exclusion of accidental or

222 unplanned pregnancies from the analysis can introduce planning bias if the likelihood of

223 accidental or unplanned pregnancy is associated with the exposure of interest. The potential

224 for planning bias was corrected for by restricting the analysis to couples who reported TTP of

$225>1$ month $(\mathrm{n}=3358)$.

226 Statistical significance was defined as a two-sided $p$-value of $<0.05$. All statistical 227 analyses were undertaken using STATA IC 14 (Stata, College Station, Texas). 


\section{Results}

Participant characteristics

230 A total of 5519 women were included in the analysis, of which $12.4 \%(n=684)$ had MetS.

231 Participant characteristics are reported in Table 1, and Figure S1 shows the participant flow.

232 The median [IQR] duration of TTP in women with and without MetS was 3 [1-11] months and 2 [1-6] months, respectively, and $22.4 \%(n=153)$ and $13.7 \%(n=660)$ were infertile at 12 months $(\mathrm{P}<0.001)$. Women with MetS had a higher BMI, a lower SEI, a higher percentage smoked, but a lower percentage consumed alcohol in the one month prior to conception (Table 1).

Table 2 shows the number and type of MetS components in all women and stratified by obesity $\left(\geq 30 \mathrm{~kg} / \mathrm{m}^{2}\right.$ vs. $\left.<30 \mathrm{~kg} / \mathrm{m}^{2}\right)$. In all 5519 women, $37.0 \%(\mathrm{n}=2040)$ had one MetS component of which high WC was most frequent $(n=1295,63.5 \%) ; 28.5 \%(n=1571)$ had two MetS components with high WC $(n=1377,87.6 \%)$ and raised glucose $(n=909,57.9 \%)$ most frequent. In the non-obese group $\left(\mathrm{n}=4685,<30 \mathrm{~kg} / \mathrm{m}^{2}\right)$, high WC was the most frequent MetS component, followed by raised glucose $(n=765,61.5 \%)$ in women with 2 components, but raised TG ( $n=321,88.2 \%)$ in women with 3 MetS components. In the obese group ( $n=833)$, all women had a high WC, and in women with an additional 2, 3 or 4 MetS components, raised TG and raised glucose were most frequent.

Relationship between MetS, its individual components, and TTP

248 The relationship between MetS and TTP is presented in Table 3. Compared to women without MetS, women with MetS had a longer TTP, after adjustment of covariates (TR 1.30; 95\% CI: 1.15-1.46). The adjusted TR for the association between MetS and TTP was similar in the nonobese and obese groups (Table 3). Marginal estimates for median TTP in women with MetS vs. without MetS was 3.1 (3.0-3.3) months vs. 4.1 (3.6-4.5) months, respectively. 
In the entire cohort (Table 3), individual components of MetS such as reduced HDL-C

$(1.37 ; 1.15-1.64)$, raised TG $(1.11 ; 1.02-1.21)$ and raised glucose $(1.11 ; 1.02-1.20)$, all associated with longer TTP. Raised BP and WC were not associated with TTP. In the obese group, reduced HDL-C demonstrated the largest adjusted TR $(1.70 ; 1.22-2.38)$, followed by raised TG $(1.24 ; 1.01-1.53)$. Raised glucose and raised BP were not associated with TTP (Table $3)$.

In the entire cohort, there was a dose response relationship with increasing number of MetS and TTP (Table 3). That is, compared to no MetS components, the adjusted TR for each additional component was $0.97(0.89-1.06)$ for 1 component, 1.08 (0.97-1.19) for 2 components, 1.21 (1.06-1.39) for 3 components, and 1.54 (1.16-2.04) for $\geq 4$ components. There was a dose response relationship with increasing number of MetS in the non-obese and obese women, such that for $\geq 4$ components--the adjusted TR was 1.45 and 2.24 , respectively. Table S1 shows a mutually adjusted model (i.e. all MetS components in the one model), reporting the association between individual components of MetS and time to pregnancy or infertility in all women.

Relationship between MetS, its individual components, and infertility

MetS and risk for infertility is presented in Table 4. Women with MetS were at a 1.62 fold (1.32-1.99) greater risk for infertility, and women were at a greater risk for infertility whether they were obese $(1.62 ; 1.15-2.29)$ or not $(1.73 ; 1.33-2.23)$. Reduced HDL-C and raised TG were the main components associated with risk for infertility.

In all women, those with $\geq 4$ MetS components had 2.06 times the risk of infertility compared to women with no MetS components (Table 4). There was a dose threshold effect with increasing number of MetS components and infertility in the non-obese women. In the 
278 to women with no MetS components.

279

280 Sensitivity analyses

281 Sensitivity analyses to evaluate possible truncation and planning bias demonstrated no

282 remarkable difference in time ratio estimates for TTP with MetS, its individual components or 283 with increasing number of MetS components (Table S2). In the truncated cohort, risk of 284 infertility was slightly increased with MetS, its individual components, and with increasing 285 number of MetS components (Table S3), and in the cohort restricted to TTP $>1$ month, risk 286 ratios for infertility were slightly attenuated with increasing number of MetS components 287 (Table S3). 
Discussion

Main Findings

290 This is the first large, population based study to assess the association between MetS, measured

291 in early pregnancy, and TTP and infertility. We report $12.4 \%(n=684)$ of women had MetS,

292 and these women took approximately one month longer to get pregnant and were at a $62 \%$

293 greater risk for infertility, irrespective of obesity status. There is minimal published data

294 measuring MetS in pregnancy, however a prevalence of 3.5\% was reported in the mother-child

295 cohort in Crete $(\mathrm{n}=625)^{27}$, up to $36.4 \%$ (depending on glycemic status) in 136 pregnant women

296 from Brazil ${ }^{28}$, and up to $36.6 \%$ (using various MetS criteria) in 675 non-diabetic, pregnant

297 Angolan women ${ }^{29}$. The current study advances the literature assessing effects of individual

298 metabolic health components and infertility by using established clustering of abnormalities

299 that elicits increasing risk with increasing number of MetS components. Our results show that

300 reduced HDL-C and raised TG appear to be major driving factors associated with delayed

301 fertility.

302

303

Strengths and Limitations

304 Strengths include the large sample size, detailed collection of maternal and paternal factors, and information on method of conception. Jukic et al. highlights the strength of retrospective

306 TTP studies in their ability to achieve a sample that is representative of the target population

307 (i.e. women planning pregnancy) as opposed to prospective TTP studies that require

308 recruitment of highly motivated couples, introducing the potential for response and planning

309 bias ${ }^{30}$. By definition, TTP relates only to periods of unprotected intercourse that end with

310 conception. Sterility or subfertility bias can be introduced if the exposure of interest is

311 associated with such severe negative impacts on fertility that women are simply not able to

312 become pregnant. In this case, the exposure will be over-represented among women who were 
313 able to become pregnant and the exposure may actually be observed to improve fertility

314 (biasing results towards the null). In reality, such negative impacts on fertility are rare and this

315 is unlikely to have influenced the results in this study. We performed a number of sensitivity

316 analyses to test the robustness of our results demonstrating no remarkable difference in time

317 ratio estimates for TTP or risk ratios for infertility with MetS.

318 Limitations include that assessment of MetS was assessed at 14-16 weeks' gestation,

319 rather than pre-pregnancy, thus we do not know whether such measurements are reflective of

320 those at the time of women trying to conceive. However, in a review of pregnant women

321 without major medical problems, compared to normal laboratory reference values for non-

322 pregnant adults, both HDL-C and TG in the first trimester demonstrated ranges that were

323 similar to non-pregnant adults ${ }^{31}$, supporting the acceptability of measuring lipids in early

324 pregnancy. For HDL-C, there were only modest increases in the second and third trimesters

325 whereas TG started to increase from the second trimester ${ }^{31}$, similar to the elevations reported

326 in smaller studies ${ }^{32,33}$. It is also unlikely that measurement of $\mathrm{WC}$, a pre-requisite for MetS

327 diagnosis, would have significantly increased at the time of recruitment at 14-16 weeks'

328 gestation ${ }^{34}$. We did not ask about menstrual cycle length which is often utilized alongside

329 defining time to pregnancy. However, previous studies have indicated that long term recall of

330 TTP has good agreement with prospective recall, assessed by questionnaires, even up to 25

331 years ${ }^{30,35,36}$. Thus it is unlikely that reporting of months for TTP rather than cycles leads to

332 misclassification of TTP.

Interpretation

335 Metabolic syndrome in the adult population is consistently associated with cardiovascular and

336 related diseases ${ }^{37-39}$. We have recently shown that using the same cohort, women with MetS

337 in pregnancy were at an increased risk for preeclampsia (RR 1.63; 95\% CI: 1.23 to 2.15 ) and 
338 gestational diabetes (RR 3.71; 95\% CI: 2.42 to 5.67 ) ${ }^{40}$; such pregnancy complications are associated with increased risk for CVD in adulthood ${ }^{41,42}$. Our data suggest that MetS may be used to broadly identify women who are at increased risk for delayed fertility, whether they are obese or not. These women may also be susceptible to future CVD risk. The utility of diagnosing MetS pre-pregnancy to predict infertility, and the impact of MetS as a function of a combination of factors or exclusion of certain factors, require investigation in other 344 pregnancy cohorts.

The association between obesity and infertility is well reported in previous studies 6,7 , infertility in non-obese women, independent of other well-known factors associated with infertility such as advanced maternal age, and cigarette use, highlights the need to consider all women in pre-pregnancy planning and antenatal care. We also found that reduced HDL-C and raised TG were the predominant factors impacting fertility, and the risk was more pronounced in the obese women.

Human mechanistic studies relating individual circulating lipoproteins and fertility is scarce $9,10,44$. However, there is extensive information characterising concentrations of lipoproteins in the oocyte ${ }^{45}$, revealing HDL-C is the most abundant lipoprotein in follicular fluid ${ }^{46}$, and appears to have the most influential role including embryo development and quality $45,47,48$. Triglycerides are found in lower amounts in follicular fluid and LDL-C is negligible ${ }^{46}$. Some human studies have demonstrated that increasing BMI associates with 358 altered metabolites in the follicular fluid ${ }^{46,49-51}$, but the evidence around an altered follicular microenvironment, oocyte quality and development, and clinical outcomes, is not strong $46,50-$ 53. Moreover, the extent to which obesity mediates this relationship has not generally been 361 significant ${ }^{50,51,54}$. Reduced HDL-C concentrations are a common feature in obese individuals $362{ }^{55}$, whereas TG are highly variable ${ }^{56}$. Yet, concentrations of HDL-C measured in follicular 
363 fluid were not different between women with lower or higher BMI, but TG in follicular fluid

364 were reduced with increasing BMI ${ }^{50,51}$. Further mechanistic examination into how circulating

365 lipoproteins impact fertility and the ovarian microenvironment in women who are obese or not,

366 is required. These results will be critical to support pre-conception counselling and current

367 antenatal care.

368

369 Conclusion

370 MetS is associated with longer TTP and infertility, independent of obesity. Additional studies,

371 pre-pregnancy, are required to support our results and to determine the applicability of which

372 combinations of metabolic abnormalities pose greatest risk to delayed fertility, or whether

373 individual components are amenable to modification. Modifications to metabolic profile may

374 subsequently reduce risk for pregnancy complications and CVD in later life.

375

376 Acknowledgements

377 JAG was supported by the NHMRC Centre for Research Excellence (GNT1099422) awarded 378 to CTR and GAD. The authors wish to thank all of the SCOPE participants and the SCOPE 379 research midwives in each centre, Robyn North for her enormous contributions in establishing 380 the SCOPE study, and Eliza Chan for her role in establishing the database. The SCOPE 381 database is provided and maintained by MedSciNet AB.

382

383 Disclosure of Interest

384 None declared. Completed disclosure of interests form available to view online as supporting 385 information.

387 Contribution of authors 
LP, LMM, LCK, JM, JJW, GAD and CTR designed the SCOPE study. JAG and LEG designed the study concept, and JAG, LEG, LGS, and SYL designed the analysis plan. JAG drafted the

390 first versions of the manuscript with subsequent contributions from LEG, LGS, PA, TBM,

391 RJN, GAD and CTR. All authors were involved in critical discussion and all authors read and

392 approved the final manuscript.

393

394 Details of ethics approval

395 Ethical approval was obtained from the relevant institutional ethic committees responsible for

396 human experimentation and all women provided written informed consent. In New Zealand,

397 approval for the SCOPE study was given by Northern Region Ethics Committee on 23/04/2003

398 reference number: AKX/02/00/364, in Australia by Central Northern Adelaide Health Service

399 Ethics of Human Research Committee on 02/09/2005 reference number: REC

400 1714/5/Application number 2005082, in London, Leeds and Manchester by the NHS South

401 East Research Ethics Committee, South East Coast Strategic Health Authority, Kent on 402 19/01/2007 reference number: 06/MRE01/98 and in Ireland by the University College Cork,

403 Teaching Hospital Research Ethics Committee on 06/02/2008 reference number: 404 ECM5(10)05/02/08.

405

406 Funding

407 The SCOPE database is provided and maintained by MedSciNet AB (http://medscinet.com).

408 The Australian SCOPE study was funded by the Premier's Science and Research Fund, South

409 Australian Government (http://www.dfeest.sa.gov.au/science- research/premiers-research-

410 and-industry-fund). The New Zealand SCOPE study was funded by the New Enterprise

411 Research Fund, Foundation for Research Science and Technology; Health Research Council

412 (04/198); Evelyn Bond Fund, Auckland District Health Board Charitable Trust. The Irish 
413 SCOPE study was funded by the Health Research Board of Ireland (CSA/2007/2;

414 http://www.hrb.ie). The UK SCOPE study was funded by National Health Service NEAT 415 Grant (Neat Grant FSD025), Biotechnology and Biological Sciences Research council (www. 416 bbsrc.ac.uk/funding; GT084) and University of Manchester Proof of Concept Funding 417 (University of Manchester); Guy’s and St. Thomas' Charity (King's College London) and 418 Tommy's charity (http://www. tommys.org/; King's College London and University of 419 Manchester); and Cerebra UK (www.cerebra.org.uk; University of Leeds). L.E. Grzeskowiak 420 is supported by an Australian National Health and Medical Research Council (NHMRC) Early 421 Career Fellowship (ID 1070421). L.C. Kenny is supported by a Science Foundation Ireland 422 Program Grant for INFANT (12/RC/2272). C.T. Roberts was supported by a National Health 423 and Medical Research Council (NHMRC) Senior Research Fellowship (GNT1020749).

424

425 The funding source(s) had no involvement in the conduct of the research nor in the preparation 426 of the manuscript. 
1. Poirier P, Giles TD, Bray GA, Hong Y, Stern JS, Pi-Sunyer FX et al. Obesity and cardiovascular disease: pathophysiology, evaluation, and effect of weight loss. Arterioscler Thromb Vasc Biol. 2006;26:968-76.

430

2. Bell LK, Edwards S, Grieger JA. The Relationship between Dietary Patterns and Metabolic Health in a Representative Sample of Adult Australians. Nutrients. 2015;7:6491505.

433

3. Stefan N, Kantartzis K, Machann J, Schick F, Thamer C, Rittig K et al. Identification and characterization of metabolically benign obesity in humans. Archives of internal

436 medicine. 2008;168:1609-16.

437 4. Wildman RP, Muntner P, Reynolds K, McGinn AP, Rajpathak S, Wylie-Rosett J et al.

438 The obese without cardiometabolic risk factor clustering and the normal weight with cardiometabolic risk factor clustering: prevalence and correlates of 2 phenotypes among the US population (NHANES 1999-2004). Archives of internal medicine. 2008;168:1617-24. 5. World Health Organisation. (2015). Sexual and reproductive health. Infertility definitions and terminology. http://www.who.int/reproductivehealth/topics/infertility/definitions/en/ Accessed 6th May 2017.

445 6. Broughton DE, Moley KH. Obesity and female infertility: potential mediators of obesity's impact. Fertility and sterility. 2017;107:840-7. 7. Zain MM, Norman RJ. Impact of obesity on female fertility and fertility treatment. Womens Health (Lond). 2008;4:183-94.

449 8. Verit FF, Yildiz Zeyrek F, Zebitay AG, Akyol H. Cardiovascular risk may be increased in women with unexplained infertility. Clin Exp Reprod Med. 2017;44:28-32. 9. Pugh SJ, Schisterman EF, Browne RW, Lynch AM, Mumford SL, Perkins NJ et al. Preconception maternal lipoprotein levels in relation to fecundability. Human reproduction. 2017;32:1055-63.

454 10. Schisterman EF, Mumford SL, Browne RW, Barr DB, Chen Z, Louis GM. Lipid concentrations and couple fecundity: the LIFE study. The Journal of clinical endocrinology and metabolism. 2014;99:2786-94.

457 11. Gleason JL, Shenassa ED, Thoma ME. Self-reported infertility, metabolic 458 dysfunction, and cardiovascular events: a cross-sectional analysis among U.S. women. $459 \quad$ Fertility and sterility. 2018.

460 12. Dekker JM, Girman C, Rhodes T, Nijpels G, Stehouwer CD, Bouter LM et al. Metabolic syndrome and 10-year cardiovascular disease risk in the Hoorn Study. Circulation. 2005;112:666-73.

463 13. Mozaffarian D, Kamineni A, Prineas RJ, Siscovick DS. Metabolic syndrome and 464 mortality in older adults: the Cardiovascular Health Study. Archives of internal medicine. 465 2008;168:969-78.

466 14. Sundstrom J, Vallhagen E, Riserus U, Byberg L, Zethelius B, Berne C et al. Risk 467 associated with the metabolic syndrome versus the sum of its individual components.

468 Diabetes care. 2006;29:1673-4.

469 15. McCowan LM, Dekker GA, Chan E, Stewart A, Chappell LC, Hunter M et al. 470 Spontaneous preterm birth and small for gestational age infants in women who stop smoking early in pregnancy: prospective cohort study. Bmj. 2009;338:b1081. 16. Fyfe EM, Rivers KS, Thompson JM, Thiyagarajan KP, Groom KM, Dekker GA et al. Elevated maternal lipids in early pregnancy are not associated with risk of intrapartum caesarean in overweight and obese nulliparous women. BMC Pregnancy Childbirth. 2013;13:143. 
17. Kenny LC, Lavender T, McNamee R, O'Neill SM, Mills T, Khashan AS. Advanced maternal age and adverse pregnancy outcome: evidence from a large contemporary cohort. PloS one. 2013;8:e56583.

18. International Diabetes Federation. IDF Consensus Worldwide Definition of the Metabolic Syndrome. The IDF consensus worldwide definition of the metabolic syndrome. Available at file://C:/Users/a1068108/Downloads/IDF_Meta_def_final.pdf. 2006. 19. NCEP. Third Report of the National Cholesterol Education Program (NCEP) Expert Panel on Detection, Evaluation, and Treatment of High Blood Cholesterol in Adults (Adult Treatment Panel III) final report. Circulation 2002; 106: 3143-421.

20. World Health Organization. Waist Circumference and Waist-Hip Ratio. Report of a WHO Expert Consultation. Geneva. 2008. Available at http://apps.who.int/iris/bitstream/handle/10665/44583/9789241501491 eng.pdf;jsessionid=6 A9DFE3CC9225CA5879B3DFDCC3994D6? sequence $=1$.

21. Klein S, Allison DB, Heymsfield SB, Kelley DE, Leibel RL, Nonas C et al. Waist Circumference and Cardiometabolic Risk: a Consensus Statement from Shaping America's Health: Association for Weight Management and Obesity Prevention; NAASO, the Obesity Society; the American Society for Nutrition; and the American Diabetes Association. Obesity. 2007;15:1061-7.

22. Davis P, McLeod K, Ransom M, Ongley P. The New Zealand socio-economic index of occupational status (NZSEI) (Research report no. 2). Wellington: Statistics NZ. 1997. Available from: http://www2.stats.govt.nz/domino/external/web/prod_serv.nsf/874ea91c142289384c2567a80 081308e/dc0ac1758236cb28cc256cef00748da5/\$FILE/NZSEI.pdf.

23. Galbraith C, Jenkin G, Davis P, Coope P. New Zealand socioeconomic index 1996: User's Guide. Wellington (NZ): Statistics New Zealand. 1996.

24. Grieger JA, Grzeskowiak LE, Bianco-Miotto T, Jankovic-Karasoulos T, Moran LJ, Wilson RL et al. Pre-pregnancy fast food and fruit intake is associated with time to pregnancy. Human reproduction. 2018.

25. Gaskins AJ, Rich-Edwards JW, Missmer SA, Rosner B, Chavarro JE. Association of Fecundity With Changes in Adult Female Weight. Obstet Gynecol. 2015;126:850-8.

26. Joffe M, Key J, Best N, Keiding N, Scheike T, Jensen TK. Studying time to pregnancy by use of a retrospective design. American journal of epidemiology. 2005;162:115-24.

27. Chatzi L, Plana E, Daraki V, Karakosta P, Alegkakis D, Tsatsanis C et al. Metabolic syndrome in early pregnancy and risk of preterm birth. American journal of epidemiology. 2009;170:829-36.

28. Negrato CA, Jovanovic L, Tambascia MA, Calderon Ide M, Geloneze B, Dias A et al. Mild gestational hyperglycaemia as a risk factor for metabolic syndrome in pregnancy and adverse perinatal outcomes. Diabetes Metab Res Rev. 2008;24:324-30.

29. Dos Prazeres Tavares H, Dos Santos DC, Abbade JF, Negrato CA, de Campos PA, Calderon IM et al. Prevalence of metabolic syndrome in non-diabetic, pregnant Angolan women according to four diagnostic criteria and its effects on adverse perinatal outcomes. Diabetol Metab Syndr. 2016;8:27.

30. Jukic AM, McConnaughey DR, Weinberg CR, Wilcox AJ, Baird DD. Long-term Recall of Time to Pregnancy. Epidemiology. 2016;27:705-11.

31. Abbassi-Ghanavati M, Greer LG, Cunningham FG. Pregnancy and laboratory studies: a reference table for clinicians. Obstet Gynecol. 2009;114:1326-31.

32. Geraghty AA, Alberdi G, O'Sullivan EJ, O'Brien EC, Crosbie B, Twomey PJ et al. Maternal Blood Lipid Profile during Pregnancy and Associations with Child Adiposity: Findings from the ROLO Study. PloS one. 2016;11:e161206. 
33. Lippi G, Albiero A, Montagnana M, Salvagno GL, Scevarolli S, Franchi M et al. Lipid and lipoprotein profile in physiological pregnancy. Clin Lab. 2007;53:173-7.

34. IOM. In: Rasmussen KM, Yaktine AL, editors. Institute of Medicine of the National Academies Weight Gain During Pregnancy: Reexamining the Guidelines. The National Academies Collection: Reports funded by National Institutes of Health: Washington (DC); 2009.

35. Baird DD, Weinberg CR, Rowland AS. Reporting errors in time-to-pregnancy data collected with a short questionnaire. Impact on power and estimation of fecundability ratios. American journal of epidemiology. 1991;133:1282-90.

36. Joffe M, Villard L, Li Z, Plowman R, Vessey M. Long-term recall of time-topregnancy. Fertility and sterility. 1993;60:99-104.

37. Doyle SL, Donohoe CL, Lysaght J, Reynolds JV. Visceral obesity, metabolic syndrome, insulin resistance and cancer. Proc Nutr Soc. 2012;71:181-9.

38. Fan J, Song Y, Chen Y, Hui R, Zhang W. Combined effect of obesity and cardiometabolic abnormality on the risk of cardiovascular disease: a meta-analysis of prospective cohort studies. Int J Cardiol. 2013;168:4761-8.

39. Ford ES, Li C, Sattar N. Metabolic syndrome and incident diabetes: current state of the evidence. Diabetes care. 2008;31:1898-904.

40. Grieger JA, Leemaqz SY, Dekker GA, Poston L, McCowan L, Kenny LC et al. Poor metabolic health, in the absence of obesity, increases risk for gestational diabetes and preeclampsia in pregnant women. Journal of Nutrition \& Intermediary Metabolism. 2017;8:77-8.

41. Lewandowski AJ, Leeson P. Preeclampsia, prematurity and cardiovascular health in adult life. Early human development. 2014;90:725-9.

42. Varner MW, Rice MM, Landon MB, Casey BM, Reddy UM, Wapner RJ et al. Pregnancies After the Diagnosis of Mild Gestational Diabetes Mellitus and Risk of Cardiometabolic Disorders. Obstet Gynecol. 2017;129:273-80.

43. Bakos HW, Mitchell M, Setchell BP, Lane M. The effect of paternal diet-induced obesity on sperm function and fertilization in a mouse model. Int J Androl. 2011;34:402-10. 44. Verit FF, Keskin S, Omer B, Yalcinkaya S, Sakar N. Is there any relationship between cardiovascular risk markers and young women with diminished ovarian reserve? Gynecol Endocrinol. 2014;30:697-700.

45. Dunning KR, Russell DL, Robker RL. Lipids and oocyte developmental competence: the role of fatty acids and beta-oxidation. Reproduction. 2014;148:R15-27.

46. Pantasri T, Wu LL, Hull ML, Sullivan TR, Barry M, Norman RJ et al. Distinct localisation of lipids in the ovarian follicular environment. Reprod Fertil Dev. 2015;27:593601.

47. Browne RW, Shelly WB, Bloom MS, Ocque AJ, Sandler JR, Huddleston HG et al. Distributions of high-density lipoprotein particle components in human follicular fluid and sera and their associations with embryo morphology parameters during IVF. Human reproduction. 2008;23:1884-94.

48. Kim K, Bloom MS, Browne RW, Bell EM, Yucel RM, Fujimoto VY. Associations between follicular fluid high density lipoprotein particle components and embryo quality among in vitro fertilization patients. J Assist Reprod Genet. 2017;34:1-10.

49. Robker RL. Evidence that obesity alters the quality of oocytes and embryos. Pathophysiology. 2008;15:115-21.

50. Robker RL, Akison LK, Bennett BD, Thrupp PN, Chura LR, Russell DL et al. Obese women exhibit differences in ovarian metabolites, hormones, and gene expression compared with moderate-weight women. The Journal of clinical endocrinology and metabolism. 2009;94:1533-40. 
576 51. Valckx SD, De Pauw I, De Neubourg D, Inion I, Berth M, Fransen E et al. BMI-

577 related metabolic composition of the follicular fluid of women undergoing assisted

578 reproductive treatment and the consequences for oocyte and embryo quality. Human

579 reproduction. 2012;27:3531-9.

580 52. Browne RW, Bloom MS, Shelly WB, Ocque AJ, Huddleston HG, Fujimoto VY.

581 Follicular fluid high density lipoprotein-associated micronutrient levels are associated with

582 embryo fragmentation during IVF. J Assist Reprod Genet. 2009;26:557-60.

583 53. Wallace M, Cottell E, Gibney MJ, McAuliffe FM, Wingfield M, Brennan L. An

584 investigation into the relationship between the metabolic profile of follicular fluid, oocyte

585 developmental potential, and implantation outcome. Fertility and sterility. 2012;97:1078-84

586 e1-8.

587 54. Dechaud H, Anahory T, Reyftmann L, Loup V, Hamamah S, Hedon B. Obesity does

588 not adversely affect results in patients who are undergoing in vitro fertilization and embryo

589 transfer. Eur J Obstet Gynecol Reprod Biol. 2006;127:88-93.

$59055 . \quad$ Rashid S, Genest J. Effect of obesity on high-density lipoprotein metabolism. Obesity. $591 \quad 2007 ; 15: 2875-88$.

592 56. McLaughlin T, Abbasi F, Lamendola C, Reaven G. Heterogeneity in the prevalence 593 of risk factors for cardiovascular disease and type 2 diabetes mellitus in obese individuals:

594 effect of differences in insulin sensitivity. Archives of internal medicine. 2007;167:642-8. 
596 Supporting information

597 Figure S1. Study flow chart for study of association of metabolic syndrome with time to

598 pregnancy.

599 Table S1 The association between individual components of metabolic syndrome and time to

600 pregnancy or infertility in all women.

601 Table S2. Primary and sensitivity analyses for the association between metabolic syndrome

602 and its individual components and time to pregnancy.

603 Table S3. Primary and sensitivity analyses for the association between metabolic syndrome 604 and its individual components and risk of infertility.

605 
Table 1 Characteristics of the study population.

\begin{tabular}{|c|c|c|c|}
\hline \multirow[t]{2}{*}{ Maternal characteristics $(n=5,519)$} & \multicolumn{2}{|c|}{ Metabolic Syndrome } & \multirow[t]{2}{*}{ p-value } \\
\hline & No & Yes & \\
\hline $\mathrm{n}$ & 4835 & 684 & \\
\hline Age (years), mean (SD) & $28.6(5.4)$ & 28.9 (5.9) & 0.596 \\
\hline Body mass index $\left(\mathrm{kg} / \mathrm{m}^{2}\right)$, mean $(\mathrm{SD})$ & $24.7(4.5)$ & $29.5(5.7)$ & $<0.001$ \\
\hline Socioeconomic index, mean (SD) & $42.1(16.6)$ & $39.4(15.7)$ & $<0.001$ \\
\hline \multicolumn{4}{|l|}{ Ethnicity, n (\%) } \\
\hline Caucasian & $4350(90.0)$ & $618(90.4)$ & 0.755 \\
\hline Other & 485 (10.0) & $66(9.7)$ & \\
\hline Smoker (pre-pregnancy), n (\%) & $1216(25.2)$ & $229(33.5)$ & $<0.001$ \\
\hline Alcohol intake (pre-pregnancy), n (\%) & $3749(77.5)$ & $495(72.4)$ & 0.003 \\
\hline \multicolumn{4}{|l|}{ Study centre, n (\%) } \\
\hline Adelaide (Australia) & $947(19.6)$ & $201(29.4)$ & $<0.001$ \\
\hline Cork (Ireland) & $1570(32.5)$ & $192(28.1)$ & \\
\hline Manchester (United Kingdom) & $277(5.7)$ & $36(5.3)$ & \\
\hline London (United Kingdom) & $173(3.6)$ & $6(0.9)$ & \\
\hline Leeds (United Kingdom) & $131(2.7)$ & $12(1.8)$ & \\
\hline Auckland (New Zealand) & 1737 (35.9) & $237(34.7)$ & \\
\hline Previous miscarriage, $\mathrm{n}(\%)$ & $657(13.6)$ & $104(15.2)$ & 0.251 \\
\hline \multicolumn{4}{|l|}{ Food group intake } \\
\hline Fast food ( $\geq 1$ time per week) & $2936(77.1)$ & $366(70.5)$ & $<0.001$ \\
\hline Fruit (<3 times per day) & $3714(76.8)$ & $573(83.8)$ & $<0.001$ \\
\hline Vegetables (<1 time per day) & $3063(63.4)$ & $453(66.2)$ & 0.143 \\
\hline Fish (<1 time per week) & $2234(46.2)$ & $369(54.0)$ & $<0.001$ \\
\hline Time to pregnancy, median (IQR) & $2(1-6)$ & $3(1-11)$ & 0.001 \\
\hline Infertile (>12 months to conceive) & $660(13.7)$ & $153(22.4)$ & $<0.001$ \\
\hline \multicolumn{4}{|l|}{ Method of conception, $n(\%)$} \\
\hline Spontaneous & $4559(94.3)$ & $613(89.6)$ & $<0.001$ \\
\hline IVF & $186(3.9)$ & $51(7.5)$ & \\
\hline Ovulation induction & $90(1.9)$ & $20(2.9)$ & \\
\hline \multicolumn{4}{|l|}{ Paternal characteristics $(n=4,300)$} \\
\hline Age (years), mean (SD) & $31.0(5.9)$ & $31.1(6.6)$ & 0.704 \\
\hline Body mass index $\left(\mathrm{kg} / \mathrm{m}^{2}\right)$, mean (SD) & $26.7(4.0)$ & $27.7(4.7)$ & $<0.001$ \\
\hline Missing ( $n=1,219$ values) & & & \\
\hline
\end{tabular}


Table 2 Number and type of metabolic syndrome components in all women and split by obesity ( $\geq 30 \mathrm{~kg} / \mathrm{m}^{2} \mathrm{vs} .<30 \mathrm{~kg} / \mathrm{m}^{2}$ ).

HDL-C=high density lipoprotein cholesterol

\begin{tabular}{|c|c|c|c|c|c|c|}
\hline & \multirow[b]{2}{*}{$\mathbf{N}$} & \multicolumn{5}{|c|}{ Metabolic syndrome component, n (\%) } \\
\hline & & $\begin{array}{l}\text { High waist } \\
\text { circumference }\end{array}$ & Raised glucose & Reduced HDL-C & $\begin{array}{c}\text { Raised blood } \\
\text { pressure }\end{array}$ & Raised triglycerides \\
\hline All women & 5519 & & & & & \\
\hline 0 & 1212 & 0 & 0 & 0 & 0 & 0 \\
\hline 1 & 2040 & $1295(63.5)$ & $454(22.3)$ & $24(1.2)$ & $7(0.3)$ & $260(12.8)$ \\
\hline 2 & 1571 & $1377(87.6)$ & 909 (57.9) & $75(4.8)$ & $47(3.0)$ & 734 (46.7) \\
\hline 3 & 586 & $575(98.1)$ & $481(82.1)$ & $127(21.7)$ & $69(11.8)$ & $506(86.4)$ \\
\hline$\geq 4$ & 109 & $109(100)$ & $104(95.4)$ & $84(77.1)$ & 37 (33.9) & $109(100)$ \\
\hline Non-Obese & 4685 & & & & & \\
\hline 0 & 1212 & 0 & 0 & 0 & 0 & 0 \\
\hline 1 & 1811 & 1067 (58.9) & $454(25.1)$ & $24(1.3)$ & $7(0.4)$ & 259 (14.3) \\
\hline 2 & 1243 & $1049(84.4)$ & 765 (61.5) & 61 (4.9) & $27(2.2)$ & $584(47.0)$ \\
\hline 3 & 364 & $353(97.0)$ & 306 (84.1) & 75 (20.6) & $37(10.2)$ & $321(88.2)$ \\
\hline$\geq 4$ & 55 & $55(100)$ & $54(98.2)$ & $48(87.3)$ & $11(20.0)$ & $55(100)$ \\
\hline Obese & 833 & & & & & \\
\hline 0 & - & & & & & \\
\hline 1 & 229 & $228(100)$ & 0 & 0 & 0 & 0 \\
\hline 2 & 328 & $328(100)$ & 144 (43.9) & $14(4.3)$ & $20(6.1)$ & 151 (45.7) \\
\hline 3 & 222 & $222(100)$ & $175(78.8)$ & $52(23.4)$ & $32(14.4)$ & 185 (83.3) \\
\hline$\geq 4$ & 54 & $54(100)$ & $50(92.6)$ & $36(66.7)$ & $26(48.2)$ & $54(100)$ \\
\hline
\end{tabular}


Table 3 The association between metabolic syndrome and its individual components and time to pregnancy in all women and split by obesity ( $\geq 30 \mathrm{~kg} / \mathrm{m}^{2} \mathrm{vs}$. $<30 \mathrm{~kg} / \mathrm{m}^{2}$ ).

HDL-C=high density lipoprotein cholesterol

NB: High waist circumference is a prerequisite for MetS and cannot be calculated

Model 1: maternal body mass index, maternal age, socioeconomic index, recruitment site, ethnicity, previous miscarriage, smoking status, alcohol intake

Model 2: model 1 plus maternal dietary intake prior to conception, paternal age, paternal body mass index

\begin{tabular}{|c|c|c|c|c|c|c|c|c|c|c|c|c|}
\hline & \multicolumn{4}{|c|}{$\begin{array}{c}\text { Entire cohort }(n=5519) \\
\text { Time ratio }(95 \% \mathrm{Cl})\end{array}$} & \multicolumn{4}{|c|}{$\begin{array}{l}\text { Non-Obese }(n=4685) \\
\text { Time ratio }(95 \% \mathrm{Cl})\end{array}$} & \multicolumn{4}{|c|}{$\begin{array}{c}\text { Obese }(n=834) \\
\text { Time ratio }(95 \% \mathrm{Cl})\end{array}$} \\
\hline & $\mathbf{N}$ & $\begin{array}{c}\text { Crude } \\
n=5519\end{array}$ & $\begin{array}{c}\text { Model } 1 \\
n=5519\end{array}$ & $\begin{array}{c}\text { Model } 2 \\
\mathrm{n}=3364\end{array}$ & $\mathbf{N}$ & $\begin{array}{c}\text { Crude } \\
n=4685\end{array}$ & $\begin{array}{c}\text { Model } 1 \\
\mathrm{n}=4685\end{array}$ & $\begin{array}{c}\text { Model } 2 \\
\mathrm{n}=2820\end{array}$ & $\mathbf{N}$ & $\begin{array}{l}\text { Crude } \\
n=834\end{array}$ & $\begin{array}{c}\text { Model } 1 \\
n=834\end{array}$ & $\begin{array}{c}\text { Model } 2 \\
n=544\end{array}$ \\
\hline & & $(1.16-1.40)$ & $(1.11-1.34)$ & $(1.15-1.46)$ & & $(1.11-1.40)$ & $(1.08-1.36)$ & $(1.11-1.50)$ & & $(1.08-1.55)$ & $(1.03-1.47)$ & $(1.08-1.69)$ \\
\hline \multicolumn{13}{|l|}{ Metabolic components } \\
\hline \multirow[t]{2}{*}{ Reduced HDL-C } & 310 & 1.15 & 1.30 & 1.37 & 208 & 1.02 & 1.17 & 1.22 & 102 & 1.47 & 1.66 & 1.70 \\
\hline & & $(1.01-1.31)$ & $(1.14-1.48)$ & $(1.15-1.64)$ & & $(0.87-1.19)$ & $(1.01-1.37)$ & $(0.99-1.51)$ & & $(1.13-1.90)$ & $(1.28-2.14)$ & $(1.22-2.38)$ \\
\hline \multirow[t]{2}{*}{ Raised triglycerides } & 1609 & 1.15 & 1.10 & 1.11 & 1219 & 1.12 & 1.08 & 1.08 & 390 & 1.24 & 1.15 & 1.24 \\
\hline & & $(1.08-1.23)$ & $(1.03-1.18)$ & $(1.02-1.21)$ & & $(1.04-1.21)$ & $(1.01-1.17)$ & $(0.98-1.18)$ & & $(1.05-1.47)$ & $(0.98-1.36)$ & $(1.01-1.53)$ \\
\hline \multirow[t]{2}{*}{ Raised glucose } & 1948 & 1.07 & 1.04 & 1.11 & 1579 & 1.05 & 1.03 & 1.10 & 369 & 1.14 & 1.08 & 1.18 \\
\hline & & $(1.00-1.14)$ & $(0.98-1.11)$ & $(1.02-1.20)$ & & $(0.98-1.13)$ & $(0.97-1.10)$ & $(1.01-1.20)$ & & $(0.96-1.35)$ & $(0.91-1.27)$ & $(0.95-1.45)$ \\
\hline Raised blood pressure & 160 & 1.13 & 1.09 & 1.03 & 82 & 1.05 & 1.08 & 0.98 & 78 & 1.15 & 1.09 & 1.12 \\
\hline \multirow[t]{2}{*}{ High waist circumference } & 3356 & 1.06 & 1.02 & 1.01 & 2524 & 1.04 & 1.01 & 1.05 & 834 & - & - & - \\
\hline & & $(1.00-1.13)$ & $(0.95-1.10)$ & $(0.92-1.11)$ & & $(0.98-1.11)$ & $(0.93-1.10)$ & $(0.94-1.17)$ & & & & \\
\hline \multicolumn{13}{|l|}{ Number of MetS components } \\
\hline 0 & 1212 & Ref & Ref & Ref & 1212 & Ref & Ref & Ref & 0 & - & - & - \\
\hline \multirow[t]{2}{*}{1} & 2040 & 0.98 & 0.98 & 0.97 & 1811 & 0.99 & 0.98 & 0.96 & 230 & Ref & Ref & Ref \\
\hline & & $(0.91-1.07)$ & $(0.90-1.06)$ & $(0.89-1.06)$ & & $(0.91-1.08$ & $(0.90-1.07)$ & $(0.86-1.07)$ & & & & \\
\hline \multirow[t]{2}{*}{2} & 1571 & 1.04 & 1.04 & 1.08 & 1243 & 1.03 & 1.02 & 1.06 & 328 & 1.22 & 1.14 & 1.30 \\
\hline & & $(0.96-1.14)$ & $(0.95-1.13)$ & $(0.97-1.19)$ & & (0.94-1.12 & $(0.93-1.12)$ & $(0.94-1.20)$ & & $(0.99-1.50)$ & $(0.93-1.39)$ & $(1.01-1.68)$ \\
\hline \multirow[t]{2}{*}{3} & 586 & 1.22 & 1.18 & 1.21 & 364 & 1.19 & 1.16 & 1.28 & 222 & 1.40 & 1.27 & 1.48 \\
\hline & & $(1.09-1.37)$ & $(1.05-1.33)$ & $(1.06-1.39)$ & & $(1.05-1.36)$ & $(1.01-1.33)$ & $(1.07-1.52)$ & & $(1.11-1.76)$ & $(1.02-1.60)$ & $(1.11-1.97)$ \\
\hline \multirow[t]{2}{*}{$\geq 4$} & 109 & 1.55 & 1.47 & 1.54 & 55 & 1.55 & 1.45 & 1.45 & 54 & 1.72 & 1.60 & 2.24 \\
\hline & & (1.24-1.95) & $(1.17-1.85)$ & $(1.16-2.04)$ & & $(1.13-2.11)$ & (1.06-1.97) & $(0.95-2.21)$ & & $(1.19-2.48)$ & $(1.12-2.29)$ & $(1.34-3.75)$ \\
\hline
\end{tabular}


Table 4 The association between metabolic syndrome and its individual components and infertility in all women and split by obesity ( $\geq 30 \mathrm{~kg} / \mathrm{m}^{2} \mathrm{vs}$. $\left.<30 \mathrm{~kg} / \mathrm{m}^{2}\right)$.

HDL-C=high density lipoprotein cholesterol

NB: High waist circumference is a prerequisite for MetS and cannot be calculated

Model 1: maternal body mass index, maternal age, socioeconomic index, recruitment site, ethnicity, previous miscarriage, smoking status, alcohol intake

Model 2: model 1 plus maternal dietary intake prior to conception, paternal age, paternal body mass index

\begin{tabular}{|c|c|c|c|c|c|c|c|c|c|c|c|c|c|c|c|}
\hline & \multicolumn{5}{|c|}{ Entire cohort $(n=5519)$} & \multicolumn{5}{|c|}{ Non-Obese $(n=4685)$} & \multicolumn{5}{|c|}{ Obese $(n=834)$} \\
\hline & \multicolumn{5}{|c|}{ Relative Risk (95\% Cl) } & \multicolumn{5}{|c|}{ Relative Risk (95\% Cl) } & \multicolumn{5}{|c|}{ Relative Risk (95\% Cl) } \\
\hline & $\mathbf{N}$ & $\%$ & $\begin{array}{c}\text { Crude } \\
n=5519\end{array}$ & $\begin{array}{c}\text { Model } 1 \\
n=5519\end{array}$ & $\begin{array}{c}\text { Model } 2 \\
n=3364\end{array}$ & $\mathbf{N}$ & $\%$ & $\begin{array}{c}\text { Crude } \\
n=4685\end{array}$ & $\begin{array}{c}\text { Model } 1 \\
n=4685\end{array}$ & $\begin{array}{c}\text { Model } 2 \\
n=2820\end{array}$ & $\mathbf{N}$ & $\%$ & $\begin{array}{l}\text { Crude } \\
n=834\end{array}$ & $\begin{array}{c}\text { Model } 1 \\
n=834\end{array}$ & $\begin{array}{c}\text { Model } 2 \\
n=544\end{array}$ \\
\hline Metabolic syndrome & 684 & 22 & $\begin{array}{c}1.64 \\
(1.40-1.92)\end{array}$ & $\begin{array}{c}1.43 \\
(1.21-1.69)\end{array}$ & $\begin{array}{c}1.62 \\
(1.32-1.99)\end{array}$ & 408 & 21 & $\begin{array}{c}1.58 \\
(1.29-1.94)\end{array}$ & $\begin{array}{c}1.45 \\
(1.18-1.77)\end{array}$ & $\begin{array}{c}1.73 \\
(1.33-2.23)\end{array}$ & 276 & 24 & $\begin{array}{c}1.59 \\
(1.19-2.12)\end{array}$ & $\begin{array}{c}1.39 \\
(1.04-1.87)\end{array}$ & $\begin{array}{c}1.62 \\
(1.15-2.29)\end{array}$ \\
\hline \multicolumn{16}{|l|}{ Metabolic components } \\
\hline Reduced HDL-C & 310 & 19 & $\begin{array}{c}1.31 \\
(1.04-1.67)\end{array}$ & $\begin{array}{c}1.49 \\
(1.17-1.89)\end{array}$ & $\begin{array}{c}1.63 \\
(1.23-2.18)\end{array}$ & 208 & 14 & $\begin{array}{c}1.02 \\
(0.73-1.43)\end{array}$ & $\begin{array}{c}1.20 \\
(0.86-1.66)\end{array}$ & $\begin{array}{c}1.36 \\
(0.90-2.05)\end{array}$ & 102 & 28 & $\begin{array}{c}1.72 \\
(1.21-2.44)\end{array}$ & $\begin{array}{c}1.97 \\
(1.35-2.86)\end{array}$ & $\begin{array}{c}1.96 \\
(1.28-3.01)\end{array}$ \\
\hline Raised triglycerides & 1609 & 18 & $\begin{array}{c}1.36 \\
(1.19-1.55)\end{array}$ & $\begin{array}{c}1.22 \\
(1.07-1.39)\end{array}$ & $\begin{array}{c}1.30 \\
(1.10-1.53)\end{array}$ & 1219 & 16 & $\begin{array}{c}1.27 \\
(1.09-1.48)\end{array}$ & $\begin{array}{c}1.17 \\
(1.01-1.36)\end{array}$ & $\begin{array}{c}1.24 \\
(1.02-1.50)\end{array}$ & 390 & 22 & $\begin{array}{c}1.57 \\
(1.17-2.11)\end{array}$ & $\begin{array}{c}1.39 \\
(1.03-1.88)\end{array}$ & $\begin{array}{c}1.64 \\
(1.14-2.35)\end{array}$ \\
\hline Raised glucose & 1948 & 16 & $\begin{array}{c}1.14 \\
(1.00-1.29)\end{array}$ & $\begin{array}{c}1.06 \\
(0.93-1.20)\end{array}$ & $\begin{array}{c}1.12 \\
(0.95-1.32)\end{array}$ & 1579 & 15 & $\begin{array}{c}1.09 \\
(0.94-1.27)\end{array}$ & $\begin{array}{c}1.05 \\
(0.91-1.21)\end{array}$ & $\begin{array}{c}1.12 \\
(0.93-1.35)\end{array}$ & 369 & 20 & $\begin{array}{c}1.23 \\
(0.92-1.64)\end{array}$ & $\begin{array}{c}1.09 \\
(0.81-1.45)\end{array}$ & $\begin{array}{c}1.16 \\
(0.83-1.62)\end{array}$ \\
\hline Raised blood pressure & 160 & 16 & $\begin{array}{c}1.11 \\
(0.77-1.58)\end{array}$ & $\begin{array}{c}0.94 \\
(0.67-1.33)\end{array}$ & $\begin{array}{c}0.93 \\
(0.59-1.45)\end{array}$ & 82 & 12 & $\begin{array}{c}0.95 \\
(0.54-1.65)\end{array}$ & $\begin{array}{c}0.91 \\
(0.56-1.50)\end{array}$ & $\begin{array}{c}0.72 \\
(0.30-1.69)\end{array}$ & 78 & 19 & $\begin{array}{c}1.08 \\
(0.67-1.74)\end{array}$ & $\begin{array}{c}0.98 \\
(0.61-1.57)\end{array}$ & $\begin{array}{c}1.08 \\
(0.64-1.83)\end{array}$ \\
\hline High waist circumference & 3356 & 15 & $\begin{array}{c}1.19 \\
(1.04-1.36)\end{array}$ & $\begin{array}{c}1.08 \\
(0.92-1.25)\end{array}$ & $\begin{array}{c}1.05 \\
(0.86-1.27)\end{array}$ & 2524 & 15 & $\begin{array}{c}1.14 \\
(0.98-1.31)\end{array}$ & $\begin{array}{c}1.09 \\
(0.92-1.30)\end{array}$ & $\begin{array}{c}1.16 \\
(0.92-1.45)\end{array}$ & 834 & 18 & - & - & - \\
\hline \multicolumn{16}{|l|}{ Number of MetS components } \\
\hline 0 & 1212 & 13 & Ref & Ref & Ref & 1212 & 13 & Ref & Ref & Ref & 0 & 0 & & & \\
\hline 1 & 2040 & 14 & $\begin{array}{c}1.02 \\
(0.85-1.22)\end{array}$ & $\begin{array}{c}0.98 \\
(0.82-1.18)\end{array}$ & $\begin{array}{c}0.90 \\
(0.72-1.13)\end{array}$ & 1811 & 14 & $\begin{array}{c}1.03 \\
(0.86-1.24)\end{array}$ & $\begin{array}{c}1.00 \\
(0.83-1.20)\end{array}$ & $\begin{array}{c}0.96 \\
(0.76-1.22)\end{array}$ & 230 & 13 & Ref & Ref & Ref \\
\hline 2 & 1571 & 14 & $\begin{array}{c}1.06 \\
(0.88-1.28)\end{array}$ & $\begin{array}{c}0.99 \\
(0.82-1.21)\end{array}$ & $\begin{array}{c}0.99 \\
(0.78-1.26)\end{array}$ & 1243 & 13 & $\begin{array}{c}1.01 \\
(0.82-1.23)\end{array}$ & $\begin{array}{c}0.97 \\
(0.79-1.20)\end{array}$ & $\begin{array}{c}1.01 \\
(0.77-1.32)\end{array}$ & 328 & 17 & $\begin{array}{c}1.32 \\
(0.87-2.01)\end{array}$ & $\begin{array}{c}1.19 \\
(0.79-1.80)\end{array}$ & $\begin{array}{c}1.42 \\
(0.85-2.37)\end{array}$ \\
\hline 3 & 586 & 21 & $\begin{array}{c}1.57 \\
(1.27-1.94)\end{array}$ & $\begin{array}{c}1.34 \\
(1.06-1.69)\end{array}$ & $\begin{array}{c}1.47 \\
(1.10-1.95)\end{array}$ & 364 & 20 & $\begin{array}{c}1.49 \\
(1.16-1.92)\end{array}$ & $\begin{array}{c}1.37 \\
(1.05-1.77)\end{array}$ & $\begin{array}{c}1.67 \\
(1.21-2.31)\end{array}$ & 222 & 23 & $\begin{array}{c}1.78 \\
(1.17-2.70)\end{array}$ & $\begin{array}{c}1.45 \\
(0.96-2.18)\end{array}$ & $\begin{array}{c}1.87 \\
(1.12-3.15)\end{array}$ \\
\hline$\geq 4$ & 109 & 29 & $\begin{array}{c}2.21 \\
(1.60-3.06)\end{array}$ & $\begin{array}{c}1.77 \\
(1.25-2.52)\end{array}$ & $\begin{array}{c}2.06 \\
(1.33-3.20)\end{array}$ & 55 & 29 & $\begin{array}{c}2.19 \\
(1.41-3.39)\end{array}$ & $\begin{array}{c}1.67 \\
(1.05-2.68)\end{array}$ & $\begin{array}{c}1.84 \\
(0.93-3.61)\end{array}$ & 54 & 30 & $\begin{array}{c}2.34 \\
(1.37-3.99)\end{array}$ & $\begin{array}{c}2.01 \\
(1.17-3.46)\end{array}$ & $\begin{array}{c}2.88 \\
(1.50-5.53)\end{array}$ \\
\hline
\end{tabular}


Table S1 The association between individual components of metabolic syndrome and time to pregnancy or infertility in all women.

HDL-C=high density lipoprotein cholesterol

Model 1: maternal body mass index, maternal age, socioeconomic index, recruitment site, ethnicity, previous miscarriage, smoking status, alcohol intake

Model 2: model 1 plus maternal dietary intake prior to conception, paternal age, paternal body mass index

\begin{tabular}{|c|c|c|c|c|c|c|c|c|}
\hline & \multicolumn{4}{|c|}{$\begin{array}{l}\text { Time to pregnancy } \\
\text { Entire cohort }(n=5519) \\
\text { Time ratio }(95 \% \mathrm{Cl})\end{array}$} & \multicolumn{4}{|c|}{ Infertility } \\
\hline & $\mathbf{N}$ & $\begin{array}{c}\text { Crude } \\
n=5519\end{array}$ & $\begin{array}{c}\text { Model } 1 \\
n=5519\end{array}$ & $\begin{array}{c}\text { Model } 2 \\
n=3364\end{array}$ & $\mathbf{N}$ & $\begin{array}{c}\begin{array}{c}\text { Crude } \\
n=4685\end{array} \\
\end{array}$ & $\begin{array}{c}\text { Model } 1 \\
n=4685\end{array}$ & $\begin{array}{c}\text { Model } 2 \\
\mathrm{n}=2820\end{array}$ \\
\hline \multicolumn{9}{|l|}{ Metabolic components } \\
\hline Reduced HDL-C & 310 & $\begin{array}{c}1.09 \\
(0.96-1.25)\end{array}$ & $\begin{array}{c}1.27 \\
(1.11-1.45)\end{array}$ & $\begin{array}{c}1.33 \\
(1.12-1.59)\end{array}$ & 310 & $\begin{array}{c}1.17 \\
(0.92-1.48)\end{array}$ & $\begin{array}{c}1.43 \\
(1.13-1.81)\end{array}$ & $\begin{array}{c}1.53 \\
(1.15-2.03)\end{array}$ \\
\hline Raised triglycerides & 1609 & $\begin{array}{c}1.13 \\
(1.06-1.21)\end{array}$ & $\begin{array}{c}1.08 \\
(1.01-1.15)\end{array}$ & $\begin{array}{c}1.08 \\
(0.99-1.18)\end{array}$ & 1609 & $\begin{array}{c}1.31 \\
(1.15-1.49)\end{array}$ & $\begin{array}{c}1.18 \\
(1.04-1.35)\end{array}$ & $\begin{array}{c}1.25 \\
(1.06-1.48)\end{array}$ \\
\hline Raised glucose & 1948 & $\begin{array}{c}1.05 \\
(0.99-1.12)\end{array}$ & $\begin{array}{c}1.03 \\
(0.97-1.10)\end{array}$ & $\begin{array}{c}1.09 \\
(1.01-1.19)\end{array}$ & 1948 & $\begin{array}{c}1.09 \\
(0.96-1.24)\end{array}$ & $\begin{array}{c}1.03 \\
(0.90-1.17)\end{array}$ & $\begin{array}{c}1.09 \\
(0.92-1.28)\end{array}$ \\
\hline Raised blood pressure & 160 & $\begin{array}{c}1.09 \\
(0.91-1.30)\end{array}$ & $\begin{array}{c}1.09 \\
(0.91-1.30)\end{array}$ & $\begin{array}{c}1.03 \\
(0.82-1.30)\end{array}$ & 160 & $\begin{array}{c}1.01 \\
(0.71-1.44)\end{array}$ & $\begin{array}{c}0.94 \\
(0.67-1.32)\end{array}$ & $\begin{array}{c}0.94 \\
(0.60-1.48)\end{array}$ \\
\hline High waist circumference & 3356 & $\begin{array}{c}1.03 \\
(0.97-1.10)\end{array}$ & $\begin{array}{c}1.02 \\
(0.95-1.10)\end{array}$ & $\begin{array}{c}1.00 \\
(0.91-1.10)\end{array}$ & 3356 & $\begin{array}{c}1.13 \\
(0.98-1.29)\end{array}$ & $\begin{array}{c}1.07 \\
(0.91-1.25)\end{array}$ & $\begin{array}{c}1.03 \\
(0.84-1.25)\end{array}$ \\
\hline
\end{tabular}


HDL-C=high density lipoprotein cholesterol

Model 1: maternal body mass index, maternal age, socioeconomic index, recruitment site, ethnicity, previous miscarriage, smoking status, alcohol intake

Model 2: model 1 plus maternal dietary intake prior to conception, paternal age, paternal body mass index

a Restricting the analysis to those with a reported starting time for pregnancy attempts between the second year and penultimate year of participant recruitment at each site

\begin{tabular}{|c|c|c|c|c|c|c|c|c|c|c|c|c|}
\hline & \multirow[b]{2}{*}{$\mathbf{N}$} & \multicolumn{3}{|c|}{ Entire cohort } & & Trunca & tio $(95 \% \mathrm{Cl})$ & & \multicolumn{4}{|c|}{$\begin{array}{l}\text { Restricted to } \\
\text { TTP>1 month }\end{array}$} \\
\hline & & $\begin{array}{c}\text { Crude } \\
n=5519\end{array}$ & $\begin{array}{c}\text { Model } 1 \\
n=5519\end{array}$ & $\begin{array}{c}\text { Model } 2 \\
n=3363\end{array}$ & $\mathbf{N}$ & $\begin{array}{l}\text { Crude } \\
n=3662\end{array}$ & $\begin{array}{c}\text { Model } 1 \\
n=3662\end{array}$ & $\begin{array}{c}\text { Model } 2 \\
n=2023\end{array}$ & $\mathbf{N}$ & $\begin{array}{c}\text { Crude } \\
n=3358\end{array}$ & $\begin{array}{c}\text { Model } 1 \\
n=3358\end{array}$ & $\begin{array}{c}\text { Model } 2 \\
n=2140\end{array}$ \\
\hline Metabolic syndrome & 684 & $\begin{array}{c}1.27 \\
(1.16-1.40)\end{array}$ & $\begin{array}{c}1.22 \\
(1.11-1.34)\end{array}$ & $\begin{array}{c}1.30 \\
(1.15-1.46)\end{array}$ & 473 & $\begin{array}{c}1.26 \\
(1.13-1.40)\end{array}$ & $\begin{array}{c}1.20 \\
(1.08-1.34)\end{array}$ & $\begin{array}{c}1.32 \\
(1.14-1.54)\end{array}$ & 454 & $\begin{array}{c}1.21 \\
(1.11-1.33)\end{array}$ & $\begin{array}{c}1.15 \\
(1.05-1.28)\end{array}$ & $\begin{array}{c}1.22 \\
(1.08-1.37)\end{array}$ \\
\hline Metabolic components & & & & & & & & & & & & \\
\hline Reduced HDL-C & 310 & $\begin{array}{c}1.15 \\
(1.01-1.31)\end{array}$ & $\begin{array}{c}1.30 \\
(1.14-1.48)\end{array}$ & $\begin{array}{c}1.37 \\
(1.15-1.64)\end{array}$ & 223 & $\begin{array}{c}1.19 \\
(1.02-1.38)\end{array}$ & $\begin{array}{c}1.33 \\
(1.14-1.55)\end{array}$ & $\begin{array}{c}1.44 \\
(1.17-1.77)\end{array}$ & 196 & $\begin{array}{c}1.16 \\
(1.02-1.33)\end{array}$ & $\begin{array}{c}1.20 \\
(1.04-1.37)\end{array}$ & $\begin{array}{c}1.20 \\
(1.01-1.43)\end{array}$ \\
\hline Raised triglycerides & 1609 & $\begin{array}{c}1.15 \\
(1.08-1.23)\end{array}$ & $\begin{array}{c}1.10 \\
(1.03-1.18)\end{array}$ & $\begin{array}{c}1.11 \\
(1.02-1.21)\end{array}$ & 1049 & $\begin{array}{c}1.15 \\
(1.06-1.24)\end{array}$ & $\begin{array}{c}1.10 \\
(1.02-1.19)\end{array}$ & $\begin{array}{c}1.14 \\
(1.02-1.27)\end{array}$ & 1020 & $\begin{array}{c}1.12 \\
(1.05-1.21)\end{array}$ & $\begin{array}{c}1.08 \\
(1.01-1.17)\end{array}$ & $\begin{array}{c}1.07 \\
(0.98-1.17)\end{array}$ \\
\hline Raised glucose & 1948 & $\begin{array}{c}1.07 \\
(1.00-1.14)\end{array}$ & $\begin{array}{c}1.04 \\
(0.98-1.11)\end{array}$ & $\begin{array}{c}1.11 \\
(1.02-1.20)\end{array}$ & 1308 & $\begin{array}{c}1.07 \\
(0.99-1.15)\end{array}$ & $\begin{array}{c}1.04 \\
(0.97-1.12)\end{array}$ & $\begin{array}{c}1.12 \\
(1.01-1.24)\end{array}$ & 1206 & $\begin{array}{c}1.06 \\
(1.00-1.14)\end{array}$ & $\begin{array}{c}1.04 \\
(0.97-1.10)\end{array}$ & $\begin{array}{c}1.06 \\
(0.98-1.15)\end{array}$ \\
\hline High waist circumference & 3356 & $\begin{array}{c}1.06 \\
(1.00-1.13)\end{array}$ & $\begin{array}{c}1.02 \\
(0.95-1.10)\end{array}$ & $\begin{array}{c}1.01 \\
(0.92-1.11)\end{array}$ & 2274 & $\begin{array}{c}1.06 \\
(0.98-1.14)\end{array}$ & $\begin{array}{c}1.01 \\
(0.93-1.11)\end{array}$ & $\begin{array}{c}1.02 \\
(0.90-1.15)\end{array}$ & 2058 & $\begin{array}{c}1.06 \\
(1.00-1.32)\end{array}$ & $\begin{array}{c}1.01 \\
(0.93-1.09)\end{array}$ & $\begin{array}{c}1.01 \\
(0.91-1.11)\end{array}$ \\
\hline Number of MetS component & & & & & & & & & & & & \\
\hline 0 & 1212 & Ref & Ref & Ref & 760 & Ref & Ref & Ref & 740 & Ref & Ref & Ref \\
\hline 1 & 2040 & $\begin{array}{c}0.98 \\
(0.91-1.07)\end{array}$ & $\begin{array}{c}0.98 \\
(0.90-1.06)\end{array}$ & $\begin{array}{c}0.97 \\
(0.89-1.06)\end{array}$ & 1375 & $\begin{array}{c}0.98 \\
(0.89-1.09)\end{array}$ & $\begin{array}{c}0.98 \\
(0.88-1.08)\end{array}$ & $\begin{array}{c}0.91 \\
(0.80-1.04)\end{array}$ & 1187 & $\begin{array}{c}1.06 \\
(0.98-1.16)\end{array}$ & $\begin{array}{c}1.03 \\
(0.95-1.13)\end{array}$ & $\begin{array}{c}1.03 \\
(0.92-1.14)\end{array}$ \\
\hline 2 & 1571 & $\begin{array}{c}1.04 \\
(0.96-1.14)\end{array}$ & $\begin{array}{c}1.04 \\
(0.95-1.13)\end{array}$ & $\begin{array}{c}1.08 \\
(0.97-1.19)\end{array}$ & 1031 & $\begin{array}{c}1.05 \\
(0.94-1.16)\end{array}$ & $\begin{array}{c}1.04 \\
(0.94-1.17)\end{array}$ & $\begin{array}{c}1.08 \\
(0.93-1.25)\end{array}$ & 972 & $\begin{array}{c}1.05 \\
(0.96-1.15)\end{array}$ & $\begin{array}{c}1.01 \\
(0.92-1.11)\end{array}$ & $\begin{array}{c}0.99 \\
(0.88-1.11)\end{array}$ \\
\hline 3 & 586 & $\begin{array}{c}1.22 \\
(1.09-1.37)\end{array}$ & $\begin{array}{c}1.18 \\
(1.05-1.33)\end{array}$ & $\begin{array}{c}1.21 \\
(1.06-1.39)\end{array}$ & 396 & $\begin{array}{c}1.18 \\
(1.03-1.36)\end{array}$ & $\begin{array}{c}1.14 \\
(0.99-1.32)\end{array}$ & $\begin{array}{c}1.23 \\
(1.01-1.49)\end{array}$ & 384 & $\begin{array}{c}1.21 \\
(1.08-1.35)\end{array}$ & $\begin{array}{c}1.14 \\
(1.01-1.29)\end{array}$ & $\begin{array}{c}1.19 \\
(1.02-1.39)\end{array}$ \\
\hline$\geq 4$ & 109 & $\begin{array}{c}1.55 \\
(1.24-1.95)\end{array}$ & $\begin{array}{c}1.47 \\
(1.17-1.85)\end{array}$ & $\begin{array}{c}1.54 \\
(1.16-2.04)\end{array}$ & 85 & $\begin{array}{c}1.64 \\
(1.27-2.11)\end{array}$ & $\begin{array}{c}1.56 \\
(1.21-2.02)\end{array}$ & $\begin{array}{c}1.82 \\
(1.26-2.63)\end{array}$ & 74 & $\begin{array}{c}1.61 \\
(1.28-2.03)\end{array}$ & $\begin{array}{c}1.48 \\
(1.17-1.88)\end{array}$ & $\begin{array}{c}1.46 \\
(1.07-2.00)\end{array}$ \\
\hline
\end{tabular}



HDL-C=high density lipoprotein cholesterol

Model 1: maternal body mass index, maternal age, socioeconomic index, recruitment site, ethnicity, previous miscarriage, smoking status, alcohol intake

Model 2: model 1 plus maternal dietary intake prior to conception, paternal age, paternal body mass index

a Restricting the analysis to those with a reported starting time for pregnancy attempts between the second year and penultimate year of participant recruitment at each site

b number and percentage of infertile women within each group (e.g. $33 \%$ of 454 women with MetS were considered infertile)

\begin{tabular}{|c|c|c|c|c|c|c|c|c|c|c|c|c|c|c|c|}
\hline & & \multicolumn{4}{|c|}{ Entire cohort } & & & Truncate & e Risk (95\% C & & \multicolumn{5}{|c|}{$\begin{array}{l}\text { Restricted to } \\
\text { TTP >1 month } \\
\text { Relative Risk }(95 \% \mathrm{Cl})\end{array}$} \\
\hline & $\mathbf{N}$ & $\%$ & $\begin{array}{c}\text { Crude } \\
n=5519\end{array}$ & $\begin{array}{c}\text { Model } 1 \\
\mathrm{n}=5519\end{array}$ & $\begin{array}{c}\text { Model } 2 \\
n=3364\end{array}$ & $\mathbf{N}$ & $\%$ & $\begin{array}{c}\text { Crude } \\
n=3662\end{array}$ & $\begin{array}{c}\text { Model } 1 \\
n=3662\end{array}$ & $\begin{array}{c}\text { Model } 2 \\
n=2023\end{array}$ & $\mathbf{N}^{b}$ & $\begin{array}{c}\text { Infertile } \\
\%^{\text {b }}\end{array}$ & $\begin{array}{c}\text { Crude } \\
n=3358\end{array}$ & $\begin{array}{c}\text { Model } 1 \\
n=3358\end{array}$ & $\begin{array}{c}\text { Model } 2 \\
n=2140\end{array}$ \\
\hline Metabolic syndrome & 684 & 22 & $\begin{array}{c}1.64 \\
(1.40-1.92)\end{array}$ & $\begin{array}{c}1.43 \\
(1.21-1.69)\end{array}$ & $\begin{array}{c}1.62 \\
(1.32-1.99)\end{array}$ & 477 & 21 & $\begin{array}{c}1.69 \\
(1.39-2.04)\end{array}$ & $\begin{array}{c}1.44 \\
(1.18-1.76)\end{array}$ & $\begin{array}{c}1.78 \\
(1.36-2.31)\end{array}$ & 454 & 33 & $\begin{array}{c}1.48 \\
(1.28-1.71)\end{array}$ & $\begin{array}{c}1.33 \\
(1.14-1.55)\end{array}$ & $\begin{array}{c}1.50 \\
(1.24-1.81)\end{array}$ \\
\hline \multicolumn{16}{|l|}{ Metabolic components } \\
\hline Reduced HDL-C & 310 & 19 & $\begin{array}{c}1.31 \\
(1.04-1.67)\end{array}$ & $\begin{array}{c}1.49 \\
(1.17-1.89)\end{array}$ & $\begin{array}{c}1.63 \\
(1.23-2.18)\end{array}$ & 224 & 19 & $\begin{array}{c}1.38 \\
(1.04-1.83)\end{array}$ & $\begin{array}{c}1.55 \\
(1.17-2.06)\end{array}$ & $\begin{array}{c}1.79 \\
(1.26-2.53)\end{array}$ & 196 & 30 & $\begin{array}{c}1.26 \\
(1.01-1.58)\end{array}$ & $\begin{array}{c}1.32 \\
(1.06-1.65)\end{array}$ & $\begin{array}{c}1.42 \\
(1.09-1.84)\end{array}$ \\
\hline Raised triglycerides & 1609 & 18 & $\begin{array}{c}1.36 \\
(1.19-1.55)\end{array}$ & $\begin{array}{c}1.22 \\
(1.07-1.39)\end{array}$ & $\begin{array}{c}1.30 \\
(1.10-1.53)\end{array}$ & 1054 & 17 & $\begin{array}{c}1.37 \\
(1.17-1.62)\end{array}$ & $\begin{array}{c}1.22 \\
(1.04-1.44)\end{array}$ & $\begin{array}{c}1.41 \\
(1.13-1.76)\end{array}$ & 1020 & 28 & $\begin{array}{c}1.28 \\
(1.14-1.45)\end{array}$ & $\begin{array}{c}1.18 \\
(1.04-1.33)\end{array}$ & $\begin{array}{c}1.24 \\
(1.06-1.44)\end{array}$ \\
\hline Raised glucose & 1948 & 16 & $\begin{array}{c}1.14 \\
(1.00-1.29)\end{array}$ & $\begin{array}{c}1.06 \\
(0.93-1.20)\end{array}$ & $\begin{array}{c}1.12 \\
(0.95-1.32)\end{array}$ & 1316 & 15 & $\begin{array}{c}1.08 \\
(0.92-1.28)\end{array}$ & $\begin{array}{c}1.01 \\
(0.86-1.19)\end{array}$ & $\begin{array}{c}1.10 \\
(0.89-1.36)\end{array}$ & 1206 & 25 & $\begin{array}{c}1.11 \\
(0.98-1.25)\end{array}$ & $\begin{array}{c}1.04 \\
(0.92-1.17)\end{array}$ & $\begin{array}{c}1.06 \\
(0.91-1.24)\end{array}$ \\
\hline Raised blood pressure & 160 & 16 & $\begin{array}{c}1.11 \\
(0.77-1.58)\end{array}$ & $\begin{array}{c}0.94 \\
(0.67-1.33)\end{array}$ & $\begin{array}{c}0.93 \\
(0.59-1.45)\end{array}$ & 119 & 19 & $\begin{array}{c}1.38 \\
(0.94-2.00)\end{array}$ & $\begin{array}{c}1.13 \\
(0.79-1.62)\end{array}$ & $\begin{array}{c}1.15 \\
(0.71-1.86)\end{array}$ & 104 & 24 & $\begin{array}{c}1.03 \\
(0.74-1.45)\end{array}$ & $\begin{array}{c}0.86 \\
(0.62-1.19)\end{array}$ & $\begin{array}{c}0.88 \\
(0.58-1.36)\end{array}$ \\
\hline High waist circumference & 3356 & 15 & $\begin{array}{c}1.19 \\
(1.04-1.36)\end{array}$ & $\begin{array}{c}1.08 \\
(0.92-1.25)\end{array}$ & $\begin{array}{c}1.05 \\
(0.86-1.27)\end{array}$ & 2286 & 15 & $\begin{array}{c}1.22 \\
(1.03-1.45)\end{array}$ & $\begin{array}{c}1.07 \\
(0.89-1.30)\end{array}$ & $\begin{array}{c}1.10 \\
(0.85-1.43)\end{array}$ & 2058 & 25 & $\begin{array}{c}1.17 \\
(1.03-1.33)\end{array}$ & $\begin{array}{c}1.06 \\
(0.91-1.22)\end{array}$ & $\begin{array}{c}1.02 \\
(0.85-1.24)\end{array}$ \\
\hline \multicolumn{16}{|l|}{ Number of MetS components } \\
\hline 0 & 1212 & 13 & Ref & Ref & Ref & 762 & 12 & Ref & Ref & Ref & 740 & 21 & Ref & Ref & Ref \\
\hline 1 & 2040 & 14 & $\begin{array}{c}1.02 \\
(0.85-1.22)\end{array}$ & $\begin{array}{c}0.98 \\
(0.82-1.18)\end{array}$ & $\begin{array}{c}0.90 \\
(0.72-1.13)\end{array}$ & 1378 & 13 & $\begin{array}{c}1.07 \\
(0.85-1.35)\end{array}$ & $\begin{array}{c}1.02 \\
(0.81-1.28)\end{array}$ & $\begin{array}{c}0.93 \\
(0.68-1.28)\end{array}$ & 1187 & 23 & $\begin{array}{c}1.07 \\
(0.90-1.27)\end{array}$ & $\begin{array}{c}1.01 \\
(0.85-1.20)\end{array}$ & $\begin{array}{c}0.97 \\
(0.78-1.20)\end{array}$ \\
\hline 2 & 1571 & 14 & $\begin{array}{c}1.06 \\
(0.88-1.28)\end{array}$ & $\begin{array}{c}0.99 \\
(0.82-1.21)\end{array}$ & $\begin{array}{c}0.99 \\
(0.78-1.26)\end{array}$ & 1036 & 13 & $\begin{array}{c}1.03 \\
(0.80-1.31)\end{array}$ & $\begin{array}{c}0.96 \\
(0.75-1.23)\end{array}$ & $\begin{array}{c}1.04 \\
(0.75-1.45)\end{array}$ & 972 & 22 & $\begin{array}{c}1.05 \\
(0.87-1.25)\end{array}$ & $\begin{array}{c}0.96 \\
(0.80-1.16)\end{array}$ & $\begin{array}{c}0.93 \\
(0.73-1.17)\end{array}$ \\
\hline 3 & 586 & 21 & $\begin{array}{c}1.57 \\
(1.27-1.94)\end{array}$ & $\begin{array}{c}1.34 \\
(1.06-1.69)\end{array}$ & $\begin{array}{c}1.47 \\
(1.10-1.95)\end{array}$ & 398 & 19 & $\begin{array}{c}1.58 \\
(1.20-2.07)\end{array}$ & $\begin{array}{c}1.31 \\
(0.98-1.76)\end{array}$ & $\begin{array}{c}1.60 \\
(1.09-2.33)\end{array}$ & 384 & 31 & $\begin{array}{c}1.46 \\
(1.20-1.78)\end{array}$ & $\begin{array}{c}1.25 \\
(1.01-1.56)\end{array}$ & $\begin{array}{c}1.37 \\
(1.05-1.79)\end{array}$ \\
\hline$\geq 4$ & 109 & 29 & $\begin{array}{c}2.21 \\
(1.60-3.06)\end{array}$ & $\begin{array}{c}1.77 \\
(1.25-2.52)\end{array}$ & $\begin{array}{c}2.06 \\
(1.33-3.20)\end{array}$ & 87 & 28 & $\begin{array}{c}2.37 \\
(1.63-3.44)\end{array}$ & $\begin{array}{c}1.84 \\
(1.23-2.77)\end{array}$ & $\begin{array}{c}2.51 \\
(1.52-4.15)\end{array}$ & 74 & 42 & $\begin{array}{c}1.99 \\
(1.48-2.67)\end{array}$ & $\begin{array}{c}1.61 \\
(1.17-2.21)\end{array}$ & $\begin{array}{c}1.72 \\
(1.14-2.60)\end{array}$ \\
\hline
\end{tabular}




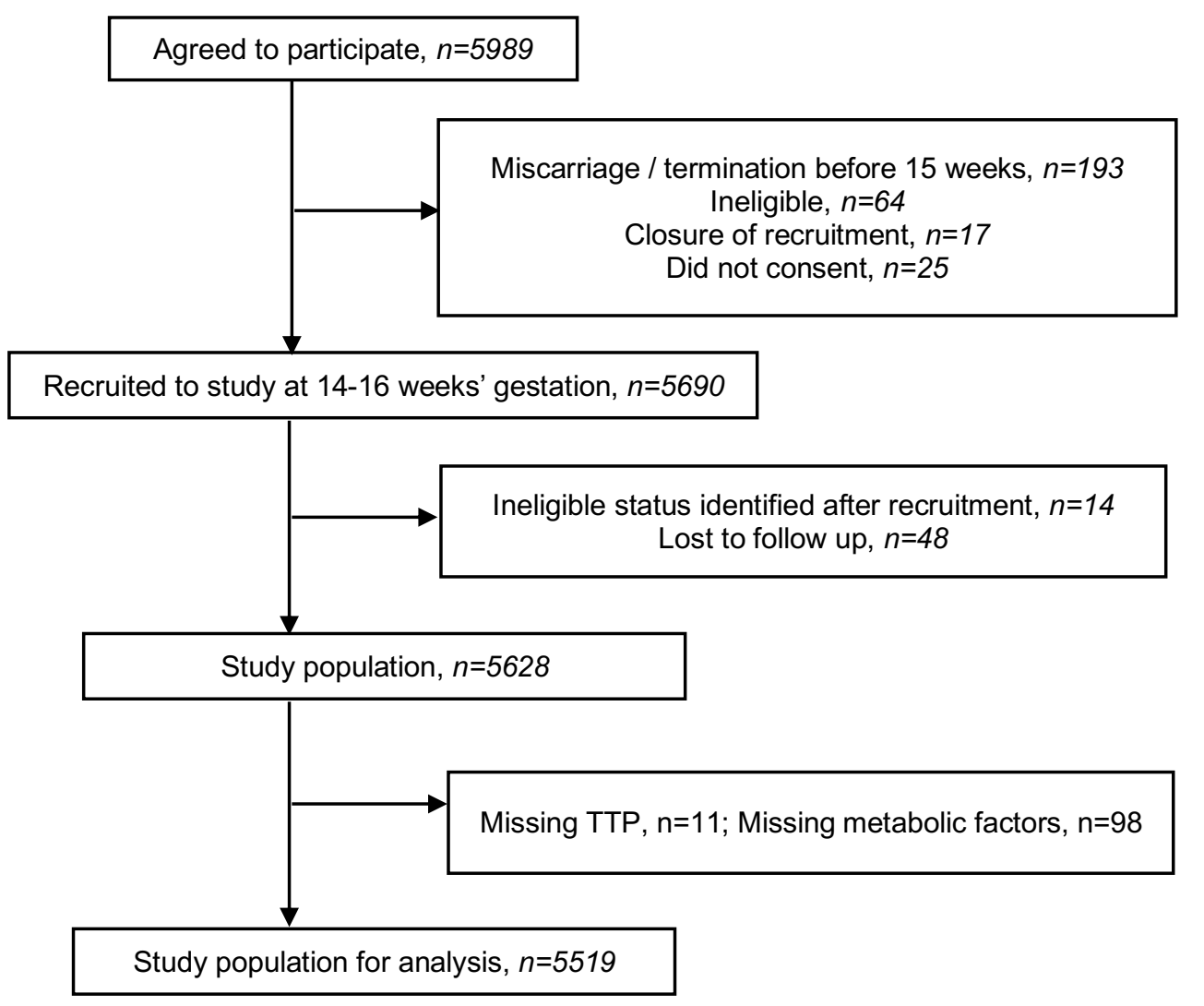

Supplemental Information

Fig S1. Study flow chart for study of association of metabolic syndrome with time to pregnancy. 